\title{
Treatment of cavitary myiasis in the face: a case report
}

\author{
Rubem Costa Araújo ${ }^{a}$, Maria Aparecida de Albuquerque Cavalcante ${ }^{a}$, Wagner Hespanhola
}

\begin{abstract}
OBJECTIVE: The word "myiasis" is derived from the Greek myio (fly) and ase (disease), and describes the infestation of humans and vertebrate animals by the larvae of flies, which feed on healthy or dead tissues of the host. The diagnosis is clinical, based on the presence of worms, and its treatment consists of the total removal of these larvae. The authors report a case of surgical debridement as a safe alternative for the treatment of cavitary myiasis in the face.

CASE DESCRIPTION: The patient, a 58-year-old male, was admitted with a cavitary lesion on the face of the right side containing fly larvae. Surgical debridement was performed in two phases, with no use of drugs or less invasive maneuvers. Total remission of the condition was achieved, but the patient died due to a squamous cell carcinoma in the posterior region of the tongue and oropharynx, a month and a half after beginning oncologic treatment.

CONCLUSION: The use of antiparasitic medication is controversial in the literature, as in specific situations this may put the patient's life at risk. Prevention is still the best way to combat an infestation by myiasis. The authors report a case of myiasis cavitation in the face using only surgical debridement as treatment
\end{abstract}

Key words: Myiasis; Debridement; Stomatology; Oral surgical procedures

\section{Tratamento de mí́ase cavitária em face: um relato de caso}

\section{RESUMO}

OBJETIVO: A palavra "míase" é derivada do grego myio (mosca) e ase (doença), e descreve a infestação em humanos e animais vertebrados vivos por larvas de dípteros, no qual se alimentam de tecidos sadios ou mortos do hospedeiro. O diagnóstico é clinico com base na presença dos vermes, e seu tratamento consiste na remoção total destas larvas. Os autores relatam um caso de desbridamento cirúrgico como opção segura para o tratamento de miíase cavitária em face.

DESCRIÇÃO DO CASO: Paciente, 58 anos, sexo masculino, foi admitido com lesão cavitária em face do lado direito contendo larvas de mosca. Foi realizado desbridamento cirúrgico em duas fases, sem associação de medicamentos ou manobras menos invasivas, com a remissão total do quadro, no entanto o paciente faleceu após um mês e meio do início do tratamento oncológico devido a um carcinoma de células escamosas na região posterior de língua e orofaringe.

CONCLUSÃO: A utilização de medicamentos antiparasitários é controversa na literatura, que em situações específicas, podem colocar o paciente em risco de vida. Prevenção ainda é a melhor maneira de combater a infestação por miíase. Os autores relataram um caso de miíase cavitária em face utilizando somente o desbridamento cirúrgico como tratamento.

Palavras-chave: Mí́ase; Desbridamento; Estomatologia; Procedimentos cirúrgicos bucais a Department of Oral and Maxillofacial Surgery, Clementino Fraga Filho Filho University Hospital HUCFF/UFRJ, Rio de Janeiro - Brazil

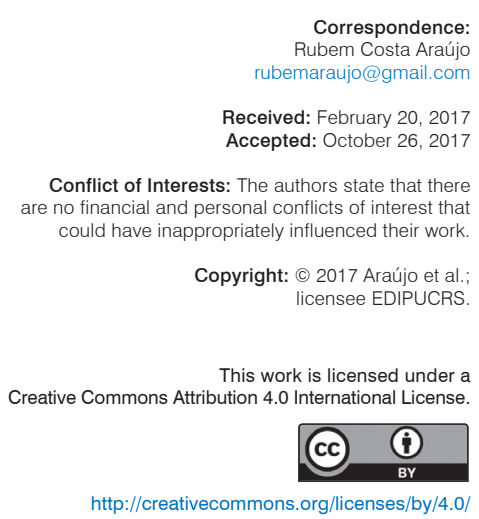

http://creativecommons.org/licenses/by/4.0/ 


\section{INTRODUCTION}

The word "myiasis" is derived from the Greek myio (fly) and ase (disease), and describes the infestation in humans and vertebrate animals by fly larvae, which feed on healthy or dead tissues of the host [1]. The eggs laid by flies will hatch into larvae, penetrate and develop in the tissue, and can survive at depth as they adhere by means of their hooks. Larval movements and the exudate that forms cause discomfort to the patient. After maturation, the larvae leave the wound to complete the cycle of development, becoming new flies [2].

A high incidence of myiasis is seen in tropical and subtropical countries, due to the prevalence flies in a warm and humid environment. When associated with local factors, such as poor sanitation and animal husbandry in rural areas, the likelihood of the manifestation of this condition increases. Other predisposing factors are reported in the literature, including psychiatric disease, hospital infection, drug addiction, mouth breathing, lip incompetence, senility, alcoholism, mental retardation, facial trauma and carcinoma [3-5].

Myiasis is classified as primary when the larvae feed on living tissue and secondary when feeding on dead tissue. In addition, classification can be based on the anatomic location involved, i.e. cutaneous, nasopharyngeal, ocular, oral, intestinal, urogenital or generalized $[1,2,6]$.

Diagnosis is clinical, based on the presence of worms, and treatment consists in the total removal of these larvae [1]. Some authors defend less invasive protocols without or with little mechanical interference, such as the use of pure petroleum jelly (Vaseline ${ }^{\circledR}$ ), beeswax, ether and/or mineral oil to occlude the cavity, causing suffocation and forcing the larvae to search for air on the surface. Other methods include the administration of ivermectin, a broad spectrum antiparasitic, with activity against ectoparasites and endoparasites with cutaneous tropism. These alternative approaches without the mechanical removal of larvae are controversial, and may be dangerous, with high potential to cause or propagate infection to other parts of the body $[2,7]$.

The objective of this study was to report on a clinical case of myiasis in the face, where only surgical debridement was performed without the use of drugs.

\section{CASE DESCRIPTION}

The patient was 58 years of age, male, Caucasian, and was admitted to the Oral and Maxillofacial Surgery and Traumatology Service, Clementino Fraga Filho University Hospital - HUCFF/UFRJ, complaining of pain in the tongue and throat, constant vomiting, dysphagia for solids for about two months and "worms in the cheek" on the right side. His companion reported having found him abandoned, locked in a room with signs of physical aggression on the face and lower limbs caused by sharp piercing objects, possibly by the patient himself. In addition, had a history of considerable weight loss, about $30 \mathrm{~kg}$ in one year, schizophrenia, chronic obstructive pulmonary disease (COPD) and epilepsy, along with long-term alcohol and tobacco use.
In the extraoral examination, he was in a generally poor state, pale, hypoglycemic, with a cavitary lesion on the right side of the face, without communication with the oral cavity, containing live fly larvae (Figure 1). In the intraoral examination, decayed dental elements and an ulcerated lesion in the posterior region of tongue and oropharynx were observed. Initially, at the ambulatory level, an incisional biopsy was performed on the tongue as well as superficial surgical debridement of the wound on the right side of the face, under local anesthesia with 2\% adrenaline and 1:100,000 epinephrine. About 35 larvae were withdrawn (Figure 2) and an occlusive dressing was placed using dry gauze and medical tape. The histopathological analysis revealed squamous cell carcinoma (SCC). The patient was hospitalized due to his unfavorable systemic condition, and received hydration as well as intravenous support medications. For the prevention of secondary infections, amoxicillin + sulbactam IV was given $8 / 8$ hours for five days.

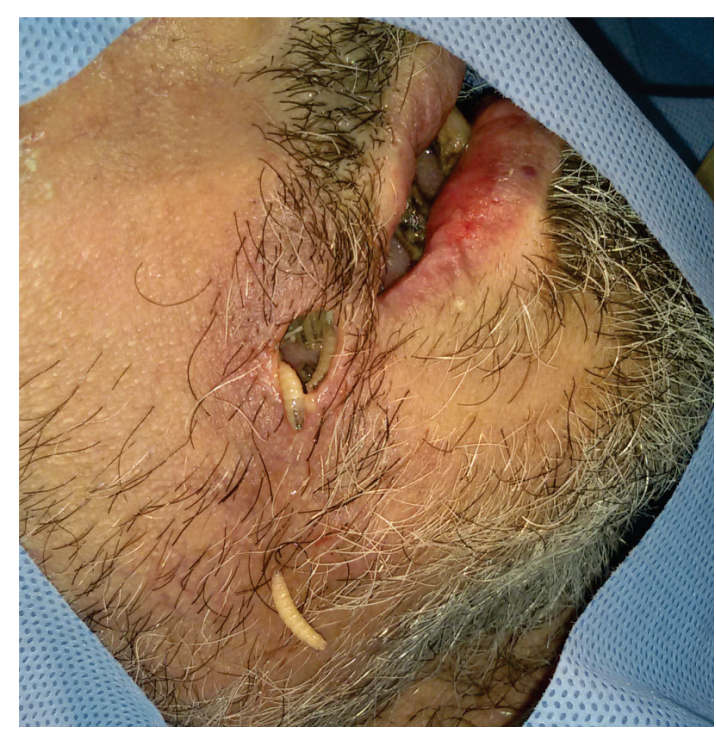

Figure 1. Right side view. Cavitary lesion on the face containing live fly larvae.

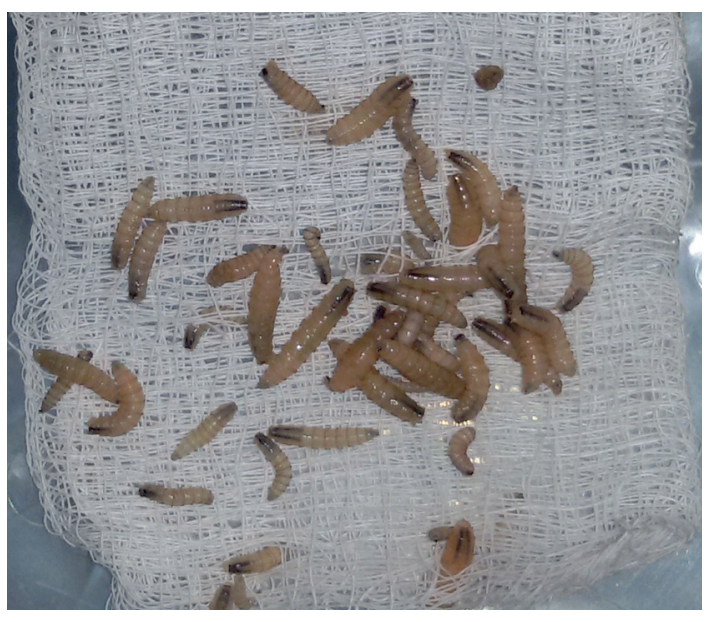

Figure 2. Thirty-five fly larvae withdrawn from a cavitary lesion in the face. 


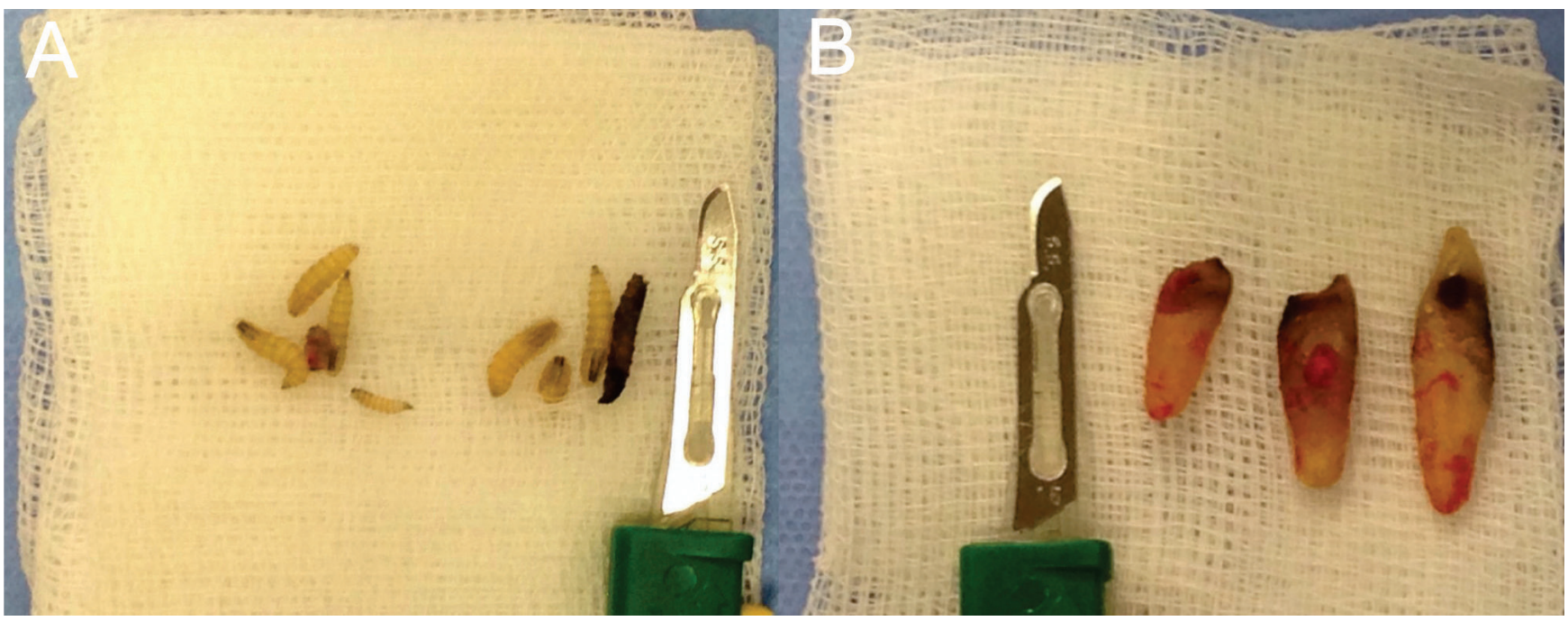

Figure 3. (A) Eight live larvae removed from a cavitary lesion in the face.

(B) Three teeth in a bad state of conservation removed from the jaw.

Because he was not a collaborative patient, and to investigate if there were larvae in the posterior region of the oral cavity, on the second day of hospitalization, a deeper surgical debridement was performed under general anesthesia. A tracheostomy was chosen since the extensive oropharyngeal lesion made it difficult to pass the tube in the naso or orotracheal manner. Eight live larvae and one dead one were removed from the wound on the face (Figure 3A). No worms were found in the lesion localized around the oropharynx and tongue. In the end, we used $0.9 \%$ saline to wash the cavity and again applied an occlusive dressing on the face, using dry gauze and medical tape. During this surgery, the last three teeth of the mandible were removed, which were in a poor state of conservation (Figure 3B).

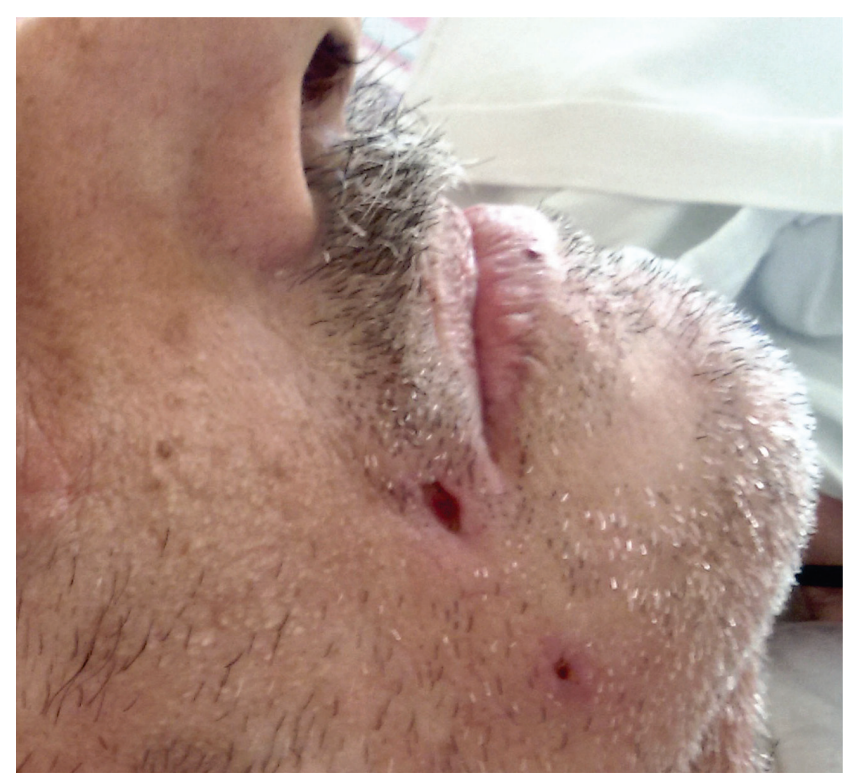

Figure 4. Patient in the lateral view. Cavitary lesion in the face with the absence of larvae in an advanced process of healing.
Seven days later, the patient was discharged from the Oral and Maxillofacial Surgery and Traumatology Service, Clementino Fraga Filho University Hospital - HUCFF/ UFRJ, with no signs of larvae in the wound, which was in an advanced process of healing (Figure 4). The patient was referred to the Oncology service of the same hospital for treatment of SCC, but died a month and a half after beginning oncologic treatment.

\section{DISCUSSION}

Cutaneous myiasis is the most common type, among the other anatomical sites, due to the exposure of the tissue to the external environment. Its highest incidence is in male patients, with a mean age of 60 years, and in warm places (an environment conducive to the reproduction of flies). In Brazil, Cochliomyia hominivorax is the most common causal agent, and is reported in the literature as the species responsible for the most serious cases of human cavitary myiasis in the modern world $[2,8]$. Factors such as poor sanitation, low income, alcoholism and mental disorders are associated with as aggravating factors in the onset of this condition $[4,5]$. In this case, the patient was 58 years old and was schizophrenic and an alcoholic. He was found by neighbors in a state of abandonment in his residence, where he lived with his 90 -year-old mother, in a suburb of the city of Rio de Janeiro, Brazil, known for its high temperatures.

The severity of myiasis depends on the location, type of injury and inflammation of the tissue [8]. Clinically, it may be classified as primary or obligatory, when the larvae feed on living tissue (biophages); this is more common in cattle and rare in humans. Secondary or optional myiasis occurs when larvae feed on dead tissue (scavengers). This is the type that usually results in cavities with necrotic lesions $[4,6]$. In the literature, the appearance of larvae has been reported in carcinomas, suggesting that necrotic and ulcerated areas exposed to the environment are a risk factor, resulting from 
negligence in advanced stage lesions. This type of tissue is attractive to many species of flies, which can deposit their eggs mainly in weakened patients, unable to perform proper hygiene [9.10]. In the reported case, the patient had SCC in the posterior region of the tongue and oropharynx. There were no larvae in these regions with necrotic tissues, probably since the cavitary lesion on the face did not have communication with the oral cavity, the preference of the fly type for living tissue, or because the malignant lesion was in a difficult to access internal organ.

The treatment of choice for cavitary myiasis is surgical debridement, and may be associated or not with the use of a systemic drug [4]. Some techniques are associated with debridement, such as the use of ether, beeswax and pure petroleum jelly (Vaseline ${ }^{\circledR}$ ), with the intention of causing suffocation, forcing the larvae to leave the wound cavity and search for air at the surface. Ivermectin, a broad spectrum antiparasitic, is the drug most often reported by authors who advocate the administration of systemic and topical drugs associated or not with the surgical removal of larvae. Administration is by the oral or topical route in humans by, and is contraindicated for children weighing less than 15 $\mathrm{kg}$ and aged less than 5 years [2.7]. In this case, surgical debridement was performed in two stages, initially at the ambulatorial level under local anesthesia and subsequently at the hospital level under general anesthesia.

Surgical debridement promotes healing, but some adverse reactions may occur in the body, such as in the case when larvae remain in the surgical site due to incomplete mechanical removal [5]. Ivermectin can cause interactions with other drugs and change the concentration of drugs routinely used by patients, as for example in the treatment of chronic diseases, such as in crisis prevention in patients with cerebral palsy. Carbamazepine is used to treat epilepsy, and has also been cited as drug with altered pharmacokinetics after the administration of the ivermectin $[2,3,10]$. In this case, the patient made use of medications to control seizures and for chronic obstructive pulmonary disease (COPD). It was decided by the authors do not use any medicine with the intention to inhibit or kill the worms.

Prevention is still the best way to combat myiasis. The use of antiparasitics is controversial in the literature, which in specific situations may put the patient's life at risk. Surgical debridement should be performed with caution to avoid leaving larvae in the wound, which would result in unsuccessful surgical treatment.

\section{REFERENCES}

1. Yadav S, Tyagi S, Kumar P, Puri. No Oral myiasis involving palate mucosa of the young female. J Nat Sci Biol Med. 2014;5(1):194-7. https://doi. org/10.4103/0976-9668.127327

2. Santos F, Bellottill A, FarahllI GJ, Camarinil ETV. Hipertratamento of myiasis due to facial trauma complex. Rev Cir Traumatol Buco-MaxiloOpt, Camaragibe. 2012 July-Sept;12:17-24.

3. Zachariah JE, Sehgal K, Dixit UB, Bhatia R. Myiasis oral: a case report Spec Care Dentist. 2014 Jan-Feb;34(1):51-3. https://doi.org/10.1111/ scd. 12016

4. Antunes AA, Santos T de S, Avelar RL, Martins Neto JV, Macedo Neres B, Laureano Son JR. Oral and maxillofacial myiasis: case series and literature review. Oral Surg Oral Med Oral Pathol Oral Radiol Endodontic. 2011 Dec;112(6):e81-5. https://doi.org/10.1016/j.tripleo.2011.05.026

5. Aggarwal, Daniel MJ, Shetty RS, Kumar BN, Sumalatha $\mathrm{CH}$, Srikanth and, Rai S, Malik. Oral myiasis caused by Chrysomya bezziana in maxilla anterior. Case Ref Dent. 2014;2014:518427

6. Kumar P, Singh V. Oral myiasis: case report and review of literature. Oral Maxillofac Surg. 2014 Mar;18(1):25-9. https://doi.org/10.1007/s10006012-0373-2

7. Ribeiro AL, de Almeida, Lopes JS Jr, Castro 3922, Pinheiro JJ. Myiasis oral: does an indication for surgical treatment still exist? Two case reports. Oral Surg Oral Med Oral Pathol Oral Radiol. 2012 Sept;114(3):e10-4. https://doi.org/10.1016/j.000o.2011.09.003

8. Provincia de N, Jadhav, Borle R, Adwani N, Khemka G Jadhav P. Primary myiasis oral: a case report. Case Ref Dent. 2012;2012:734234.

9. Al-Maweri SA Al-Sufyani GA, Tarakji B, Abdulrab s. Myiasis associated with oral squamous cell carcinoma - a literature review. Asian Pac J Cancer Prev. 2015;16(12):4997-9. https://doi.org/10.7314/APJCP.2015.16.12.4997

10. Biradar S, Wankhede P, Munde, Shaikh S. Extensive myiasis infestation associated with oral squamous cell carcinoma: report of two cases. Dent Res J (Isfahan). Jan-Feb 2015;12(1):100-5. https://doi.org/10.4103/17353327.150343 